Article

\title{
Adaptive Procurement Guidelines for Automatic Selection of Renewable Forest Energy Sources within a Sustainable Energy Production System
}

\author{
Teijo Palander ${ }^{1, *}$ and Kalle Kärhä ${ }^{2}$ \\ 1 Faculty of Science and Forestry, University of Eastern Finland, P.O. Box 111, Joensuu FI-80101, Finland \\ 2 Stora Enso Wood Supply Finland, P.O. Box 309, Helsinki FI-00101, Finland; kalle.karha@storaenso.com \\ * Correspondence: teijo.s.palander@uef.fi; Tel.: +358-40-9603748
}

Academic Editor: Dimitris S. Argyropoulos

Received: 31 December 2015; Accepted: 25 February 2016; Published: 3 March 2016

\begin{abstract}
An automatic forest-stand selection method was developed that integrates the procurement of profitable energy sources within a sustainable energy production system. We tested the method using a forest harvester simulator. We found that site-specific estimates of forest characteristics are important when predicting the potential of an energy-wood stand as a renewable energy source. Further, tree parameters can be combined with automatic stem measurements from a multiple-tree harvester to predict the energy-wood biomass in the stands. The selection process uses data from profitability studies. The selection process also uses environmental criteria to ensure that sufficient soil organic matter is left behind and to protect the soil against erosion. The integrated system of the harvester automatically adapts the system's models and stand-selection rules to account for various site-specific stand parameters. Predicting the profitable and environmentally acceptable yield of stand biomass has great potential in sustainable forest resource management, but managers must decide whether the operational procurement guidelines provided by the stand-selection method is acceptable under their local real-world wood procurement conditions.
\end{abstract}

Keywords: automation; energy-wood; profitable; renewable; sustainable

\section{Introduction}

In most countries in Europe, biomass resources are small compared to the European energy balance [1]. However, in Finland, forest biomass provides the potential of a 50\% increase of renewable fuels for distributed bio-based economy. Along with economic sustainability, based on the idea of continuous forest yield, environmental sustainability has become a serious issue in Finland's forest management debate [2]. Since the mid-1990s, commitments to sustainable energy-wood cutting have strengthened in Finnish forestry. Therefore, the development of future district heating systems and technologies involves forest fuel procurement measures as an important part of such technology [3].

The design of sustainable energy systems, including regional resource management systems, are described in a number of recent studies [4-9]. Typically, Geographic Information Systems (GISs) are used in energy planning. The concepts of sustainable regional source and land use management have been presented by Yamamoto et al. [4]. Their system analyzes the overall biomass flows and geographic region resource management is strongly linked to the land management strategy for sustainable development, in which the biomass flow has the characteristics of spatial planning [7]. The strategic energy planning is usually focused on social and economic needs with integral considerations of the environment to be sustainable in the long-term environment.

In the short-term planning, the local and distributed nature of the forest biomass resource and it's usually low energy density require energy supply chains with large harvesting (cutting and 
forwarding) and transportation capacities [3,7]. The operational interactions between parameters of supply chains, such as stem diameter, log length, wood moisture content, dry matter, solid density, bulk density, energy content, truck payload, and road infrastructure constraints, are complex and need to be properly evaluated in order to deliver the material efficiently $[8,10,11]$. It shows that there will be a demand for local stand selection systems, designed to improve productive and cost-efficient forest work in sustainable wood cutting operations. The concept of decentralized wood procurement has been presented by Palander [11]. According to Palander, local wood procurement planning in the forest industry encompasses a wide range of operational decisions, from forest to plants, and decision support systems can help managers during the complex planning process [11]. Therefore we developed a decision support system for stand selection of energy-wood cutting.

The growing demand for energy wood forms an environmental and economical trade-off. The intensive harvesting of stand areas required for growing energy crops and refining them into marketable fuels can result in reduced energy wood price and loss of biodiversity $[2,5,12]$. In the Finnish forest industry, young stands have became a potential source of wood within a sustainable energy production system, which is important in the context of a growing demand to increase the use of renewable energy sources [13-15]. To achieve sustainability targets while minimizing wood cutting expenses, managers must understand the effects of energy-wood cutting on the natural processes of forests. Therefore, studies on the effects of cutting practices, including energy-wood removal, on forest diversity have received much attention since the $2000 \mathrm{~s}$ [16-18]. High-risk forests have been identified, where energy-wood cutting is not recommended, and measures have been developed to minimize the environmental impact on medium- and low-risk forests. These measures will assist the managers of the forest industry to identify sites where young stands can be cut without compromising both long-term and short-term sustainability. In the literature of forest management planning (cf. [13]), young stands are determined as stands:

- from which wood harvested is only energy wood and/or pulpwood, and

- where the mean diameter at breast height is less than $16 \mathrm{~cm}$, but more than $3 \mathrm{~cm}$, and

- where the height of dominant trees is more than $7 \mathrm{~m}$ in Scots pine (Pinus sylvestris L.) and Norway spruce (Picea abies (L.) Karst.) dominated stands, and more than $9 \mathrm{~m}$ in broadleaf stands.

In practice, young stands also contains larger trees, which must be cut in mechanized first thinning. Around two thirds of the wood harvested from young stands come from Scots pine-dominated stands in Finland. During the $2000 \mathrm{~s}$, the average stem size of young stands has been $82 \mathrm{dm}^{3}$, the average industrial pulpwood removal $47 \mathrm{~m}^{3} \cdot \mathrm{ha}^{-1}$, and the forest haulage distance $295 \mathrm{~m}$. In 2014, the average harvesting (cutting and forest haulage) costs of pulpwood in first thinnings carried out by the Finnish forest industries was $17.7 € \cdot \mathrm{m}^{-3}$. When producing whole-tree chips from young stands for energy generation, the total supply chain costs are approximately $18-24 € \cdot \mathrm{MWh}^{-1}$ of which the harvesting costs were around $40 \%-50 \%[13,19]$.

In Finnish forests, energy-wood cutting is carried out only on suitable sites where stands meet the criteria for short-term environmental sustainability [20]. For example, stands with a diversity of less than required are not harvested using energy wood assortments. Suitable stands must also meet economic criteria set by the harvesting entrepreneur and the wood procurement company for profitable cutting, such as having acceptable logistics costs for transport of the energy wood to energy plants. Typically, the harvested areas must be located within $100 \mathrm{~km}$ from the energy plants [5]. In this study, profitability of energy-wood cutting will be integrated with selection of trees in stand harvesting planning. To predict reliable yield of stand for an energy-wood entrepreneur, selection of trees will also be integrated with biomass calculations by model of Repola et al. [21]. Obtaining reliable predictions of stand biomass requires local site-specific guidelines that can be applied to guide the management of stand harvesting [22].

Nowadays, energy-wood cutting is a common practice in Finland, and efficient methods for forest silviculture have been developed to make this form of cutting sustainable [20]. Energy-wood cutting 
can also be combined with pulpwood cutting [23], although this increases the cost of conventional cutting. After energy-wood cutting, there are short-term effects on sustainability, and these effects are soil-, site-, and practice-specific [16-18]. The effects can be managed and controlled by a harvester operator. In practice, harvester operators are charged with deciding how many trees to leave per hectare, and they select trees conventionally without assistance from decision-support and control software. Therefore, sustainability problems arise as a result of the selection of trees by harvester operators.

Recently, researchers have developed operational stand-selection systems and suggested that the tree-selection rules that are in current use need improvement. For instance, control of cutting could be based on site-specific measurements of each tree in a stand [23,24]. In addition to the energy wood volume, the exact stem diameter and location (using an onboard GPS receiver and machine vision) could be determined based on these measurements. These measurements can be obtained and analyzed automatically using work study software, such as John Deere's TimberLink $[25,26]$. In the present study, we developed software to identify data from each stem that could be used to develop potential operating rules to increase the efficiency and environmental sustainability of energy-wood cutting. We then tested the potential of this software (system) in simulation of stand selection using real production data collected by a multiple-tree harvester's computer.

In Finland, wood procurement organizations use automatic logistics systems to achieve their procurement targets while minimizing operating costs. Therefore, managers need accurate estimates of stand characteristics for their management information systems so they can accurately quantify the amount of energy wood that is available as a profitable energy source. To meet their needs, the present study was designed to construct an automatic adaptive system to select profitable stands from suitable stands that would permit environmentally sustainable energy-wood cutting within an operational stand-selection system (Figure 1). We solved the research problem by integrating site-specific stem-related information, recorded by a John Deere multiple-tree harvester with profitability information obtained for the same harvester. The solution also provides practical tree-selection rules used to cut the young stands by the harvester operator.

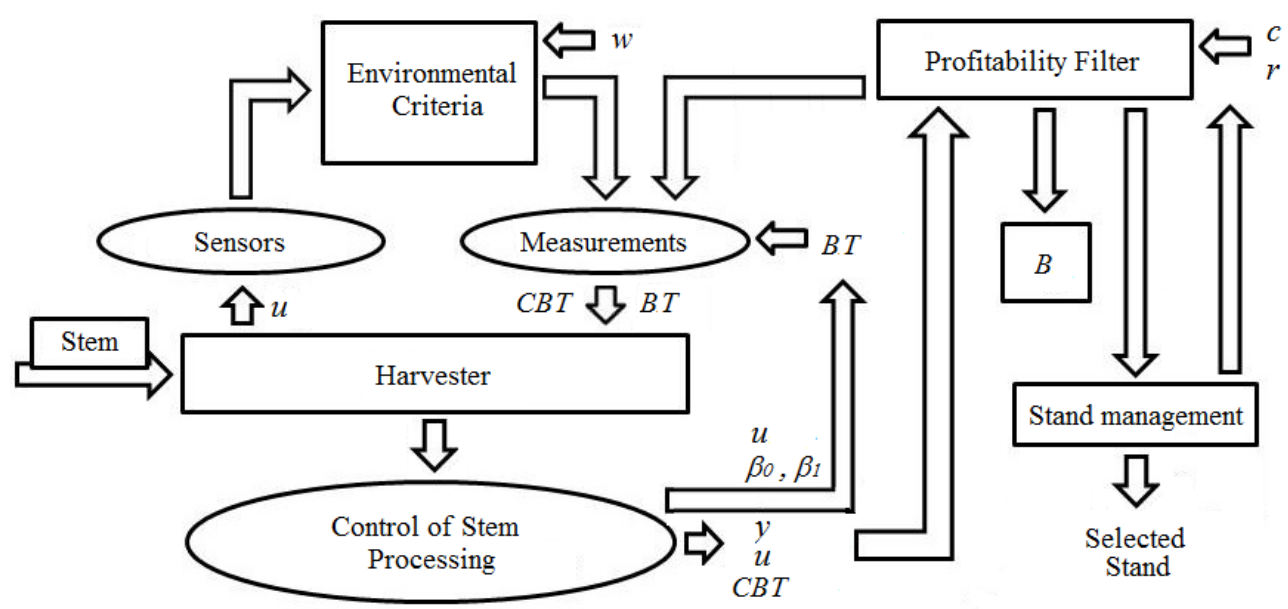

Figure 1. The stand-selection system. $u$, stem diameter; $w$, environmental parameter; $B T$, volume from the biomass equation; $C B T$, volume from the calibrated biomass equation; $B$, the stand biomass $\left(\mathrm{m}^{3}\right.$ per stand); $y$, cutting times; $c$, costs; $r$, revenues; $\beta_{0}$ and $\beta_{1}$, regression parameters.

\section{Materials and Methods}

\subsection{Harvester Stem Data}

The automatic stem data was collected from one stand (i.e., logging site) in Orimattila in Finland $\left(60^{\circ} 48^{\prime} \mathrm{P}, 25^{\circ} 44^{\prime} \mathrm{E}\right)$. Thinning of the stand was conducted using a John-Deere multiple-tree harvester, 
and the area of the thinning site was 8.8 ha. Cutting instructions and intensities were equal on the site, but site volume $\left(\mathrm{m}^{3} \cdot \mathrm{ha}^{-1}\right)$ varied inside the site before cutting. Therefore, the total removal of energy and pulp wood from the stand ranged from $35 \mathrm{~m}^{3} \cdot \mathrm{ha}^{-1}$ to $74 \mathrm{~m}^{3} \cdot \mathrm{ha}^{-1}$ and averaged $59.9 \mathrm{~m}^{3} \cdot \mathrm{ha}^{-1}$. The harvester data consisted of 5125 stems: Norway spruce $(9 \%)$, Scots pine $(73 \%)$, and Silver birch (Betula pendula Roth., 18\%). The measurements for each stem were stored in files that were transmitted daily to the entrepreneur's enterprise-resource-planning system via a mobile phone network connection. The harvester's sensor recorded stem diameters along the pulp wood stem at $10-\mathrm{cm}$ intervals, starting from the lowest cutting point and ending at the last cutting height. The harvester recorded one diameter along the energy-wood stem at the cutting point. In the calculation system used in this study [24], the stem data were combined into a single file (the stem database), which contained information on the tree species, stem diameters and stem height.

For pulp wood stems we calculated the diameter at breast height $(\mathrm{dbh}, 130 \mathrm{~cm})$ by linear interpolation between the measurement diameters above and below this height, with the distance between the measurements on the stem used to estimate the position of dbh between these two diameters. For energy-wood stems we also used the time and motion study data in the calculation of these stem characteristics. Tree height included parts above the highest cut that were not harvested. To derive the relative position of each diameter measurement along the stem, the total tree height must be estimated. To do so, we estimated the length of the top part of the stem (i.e., the part above the highest cut position) for each tree using the model published by Varjo [27]. The total tree height was computed as the sum of the height at the top cut and the estimated length of the top part of the stem above this cut based on the harvester measurements and Varjo's model.

\subsection{Harvester's Profitability Data in Operational Planning}

Profitability data were collected in 12 stands in 2009, when an experienced harvester operator carefully selected trees either for multiple-tree processing or single-tree processing. We used a general work cycle model of cutting that also facilitated the use of automatically recorded data [28]. The data were used in the cost calculation of the stand-selection system. The energy-wood cutting costs amounted to $65 € /$ E15-hour. The price of the harvester was 230,000 $€$ (at $0 \%$ VAT). The total annual work cycle was 2240 operating hours (E15-hours, which include delay times shorter than $15 \mathrm{~min}$ ). The depreciation period for the base machine and the harvesting head were both set to 5.0 years. The operator's salary was set to $14.7 € / E 15$-hour, including indirect salary costs (59\%) and including an amount for compensated travel time. The fuel consumption for the machine was $12 \mathrm{~L} / \mathrm{E} 15$-hour at $1.07 € / \mathrm{L}$ [29]. Repair and service costs were estimated to be $3.0 € /$ E15-hour, administration, maintenance, and insurance costs were $4400 €$ per year.

The energy-wood cutting cost decreases significantly as stem diameter increases [30]. For example, the cost decreases by $30 \%$ as the stem diameter increases from $5 \mathrm{~cm}$ to $20 \mathrm{~cm}$, representing a change from $35 € \cdot \mathrm{m}^{-3}$ Sob to $25 € \cdot \mathrm{m}^{-3}$ Sob (solid volume, scaled outside the bark), respectively. When the stem diameter is $30 \mathrm{~cm}$, the energy-wood cutting costs are $22.5 € \cdot \mathrm{m}^{-3}$ Sob. When the stand diameter is $40 \mathrm{~cm}$, the energy-wood cutting costs are $20 € \cdot \mathrm{m}^{-3}$ Sob. When energy-wood cutting is integrated with pulp wood cutting, this operation decreases the costs of cutting by $5 \%$ to $10 \%$, compared to cutting without the integrated technique [23,31]. In practice, wood procurement companies pay entrepreneurs an average cutting revenue that was $8.9 € \cdot \mathrm{m}^{-3}$ sob in the present study.

\subsection{Stand-Selection System}

In our simulation study, one young stand was cut stem by stem using the stand-selection system. The profitability of stem cutting (by the entrepreneur) and of stand procurement (by the energy producer) must both be considered in the stand-selection system, because the productivity and cost-efficiency of stem cutting increases with increasing stem diameter [13,24]. In addition, energy producers pay the entrepreneur. To test the system and calculate the entrepreneur's profitability, we developed a method from a recent automatic time and motion study [24]. The stem-cutting time (s) 
was calculated for the diameter at the $\mathrm{dbh}$, and the resulting operational profitability data were analyzed. Yield of stand was calculated by model of Repola et al. [21]. In this study, to maintain entrepreneur's profitability, the average hourly operating cost must be less than $65 € /$ E15-hour for the harvester.

The stem-selection process mined stem data from the stand into energy wood and pulp wood files. The selection process identified energy-wood stem, following the company's selection criteria for sustainable energy production. In practice, due to environmental sustainability criteria and watershed protection guidelines, tops and branches from the largest $75 \%$ of the trees were left in the forest. We also left small trees (Norway spruce) to increase biodiversity and to avoid a decrease in soil C. The heuristic energy-wood rules used to select stems for multiple-tree processing were the following:

- $\quad$ Step 1: The tree species is not spruce and stem belongs to the energy-wood diameter $(<16 \mathrm{~cm})$ frequency distribution.

- $\quad$ Step 2: The diameter at dbh height is less than or equal to $8 \mathrm{~cm}$.

- $\quad$ Step 3: The diameter of next tree at dbh height is less than or equal to $8 \mathrm{~cm}$.

In this process, the tree species and diameter can be considered as a kind of economic criterion for energy-wood procurement by means of stem cutting. To mine the stem data more efficiently for stand selection, we developed a process that integrated the profitability criterion with the criteria for environmentally sustainable energy-wood cutting (Figure 1). We computed profitability using a harvester simulator's onboard computer [32]. The onboard computer was similar to that used by machines in the forests, and the software was programmed accordingly.

We developed software that let us automatically obtain detailed data for each stem. The software identified the tree characteristics used for stand selection based on the protocols of the adaptive system controller (Figure 2). During the energy-wood cutting experiment, the software automatically monitored the diameter and compared it with the stand-selection rules for the stand. The resulting data were also automatically downloaded to a database after the experiment. To facilitate our analysis the software displayed work reports that let us compare stand-cutting expenses and revenues across a range of diameters.

Automatic data collection and data mining

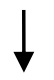

Actual model in the adaptive controller

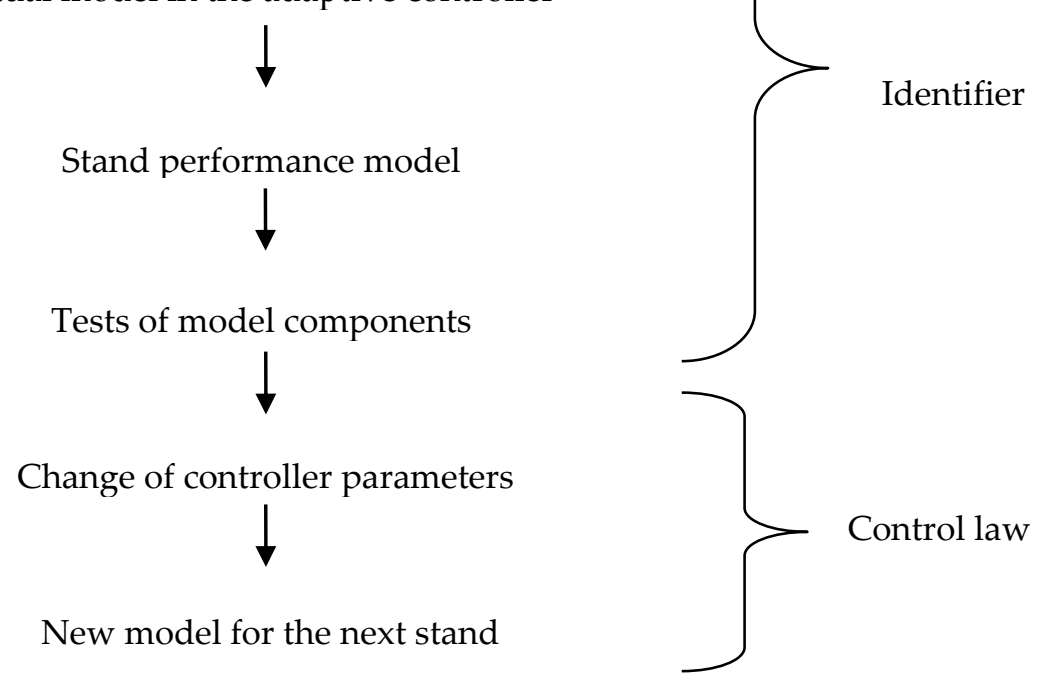

Figure 2. Elements of the adaptive control system. 


\section{Results}

Several stand-selection processes were analyzed based on tree characteristics. The best process classified trees into two groups: trees of which stems, top parts and branches were probably cut for energy, and trees (pulpwood) of which top parts and branches were probably left in the forest. The process identified trees by integrating the economic selection criteria with the criteria for environmentally sustainable energy-wood cutting (Figure 1).

Initially, trees were defined as energy wood if they were not spruce, had a diameter at dbh height $\leqslant 8 \mathrm{~cm}$ and belonged to small trees of the diameter frequency distribution. In practice, the manager can examine the frequency distribution for diameter at dbh height that is generated by the harvester computer and can determine whether a given sample or stand met the criteria using the information in Tables 1 and 2.

Table 1. Stand parameters for each diameter class in time-study report of the multiple-tree harvester. $\mathrm{dbh}$, diameter at breast height; $\mathrm{nt}$, number of trees; ha, hectare; s, second; $\mathrm{m}^{3}$, cubic meter (solid volume, scaled outside the bark).

\begin{tabular}{|c|c|c|c|c|c|}
\hline $\begin{array}{l}\text { Stem Diameter } \\
\text { Class (dbh, cm) }\end{array}$ & $\begin{array}{l}\text { Mean Diameter } \\
(\mathrm{dbh}, \mathrm{cm})\end{array}$ & $\begin{array}{l}\text { Stem Frequency } \\
\left(\mathbf{n t} \cdot \mathbf{h a}^{-1}\right)\end{array}$ & $\begin{array}{l}\text { Stem Cutting } \\
\text { time (s) }\end{array}$ & $\begin{array}{c}\text { Stem } \\
\text { Volume }\left(\mathrm{m}^{3}\right)\end{array}$ & $\begin{array}{c}\text { Stand } \\
\text { Volume }\left(\mathrm{m}^{3}\right)\end{array}$ \\
\hline $3-5.9$ & 5.4 & 171 & 14.07 & 0.009 & 1.52 \\
\hline $6-7.9$ & 7.0 & 488 & 14.06 & 0.013 & 6.18 \\
\hline $8-9.9$ & 8.8 & 272 & 14.96 & 0.020 & 5.50 \\
\hline $10-11.9$ & 10.8 & 74 & 15.56 & 0.028 & 2.09 \\
\hline $12-13.9$ & 12.8 & 15 & 16.89 & 0.043 & 0.64 \\
\hline $14-15.9$ & 14.2 & 5 & 20.61 & 0.054 & 0.27 \\
\hline $16-17.9$ & 16.9 & 4 & 20.09 & 0.065 & 0.26 \\
\hline $18-9.9$ & 18.4 & 3 & 25.90 & 0.080 & 0.24 \\
\hline $20-21.9$ & 21.3 & 2 & 24.19 & 0.104 & 0.21 \\
\hline $22-49.9$ & 37.4 & 8 & 31.42 & 0.283 & 2.27 \\
\hline
\end{tabular}

Table 2. Work-study parameters and profit calculations for each diameter class in a representative stand. Energy-wood cutting subsidies were $7 € \cdot \mathrm{m}^{-3} ; \mathrm{m}^{3}$, cubic meters (solid volume, scaled outside the bark); dbh, diameter at breast height; E15-hour, operating hours, including delays shorter than $15 \mathrm{~min}$.

\begin{tabular}{|c|c|c|c|c|c|c|c|}
\hline $\begin{array}{c}\text { Stem Diameter } \\
\text { Class }\end{array}$ & $\begin{array}{c}\text { Cutting } \\
\text { Productivity }\end{array}$ & $\begin{array}{c}\text { Cutting } \\
\text { Cost }\end{array}$ & $\begin{array}{l}\text { Cutting } \\
\text { Revenue }\end{array}$ & $\begin{array}{c}\text { Cutting } \\
\text { Revenue }\end{array}$ & $\begin{array}{c}\text { Stem Profit } \\
\text { without Subsidies }\end{array}$ & $\begin{array}{c}\text { Stem Profit } \\
\text { with Subsidies }\end{array}$ & $\begin{array}{c}\text { Stand Profit } \\
\text { with Subsidies }\end{array}$ \\
\hline$(\mathrm{dbh}, \mathrm{cm})$ & $\left(\mathrm{m}^{3} /\right.$ E15-hour) & $\left(€ \cdot m^{-3}\right)$ & (€/E15-hour) & $\left(€ \cdot \mathrm{m}^{-3}\right)$ & $\left(€ \cdot m^{-3}\right)$ & $\left(€ \cdot m^{-3}\right)$ & (€) \\
\hline $3-5.9$ & 2.28 & 28.51 & 11.68 & 8.9 & -19.61 & -12.61 & -18.93 \\
\hline $6-7.9$ & 3.12 & 20.83 & 27.80 & 8.9 & -11.93 & -4.93 & -30.47 \\
\hline $8-9.9$ & 4.87 & 13.34 & 43.37 & 8.9 & -4.44 & 2.66 & 14.63 \\
\hline $10-11.9$ & 6.54 & 9.94 & 58.24 & 8.9 & -1.04 & 5.96 & 12.46 \\
\hline $12-13.9$ & 9.08 & 7.15 & 70.84 & 8.9 & 1.75 & 8.75 & 5.60 \\
\hline $14-15.9$ & 9.43 & 6,89 & 83.96 & 8.9 & 2.01 & 9.01 & 2.43 \\
\hline $16-17.9$ & 11.60 & 5.60 & 103.27 & 8.9 & 3.30 & 10.30 & 2.68 \\
\hline $18-19.9$ & 11.07 & 5.87 & 98.55 & 8.9 & 3.03 & 10.03 & 2.41 \\
\hline $20-21.9$ & 15.42 & 4.21 & 137.27 & 8.9 & 4.69 & 11.69 & 2.46 \\
\hline $22-49.9$ & 32.47 & 2.00 & 289.01 & 8.9 & 6.90 & 13.90 & 31.55 \\
\hline
\end{tabular}

Our control system computed the acceptable parameters for harvestable stems in stand following the protocol in Figure 2. To study the procurement guidelines, we analyzed site-specific data. The best-fit rules classified trees using stand diameter classes, costs, revenues and profits. The entrepreneur's cutting revenue must equal or exceed the cutting cost to earn a profit, and thus must be at least $65 € / E 15$-hour. As an example of the stand selection process, Table 2 summarizes the cutting profits for the observed stem-diameter classes based on the average diameters in each class for the stems. In this particular sample of stand, the average revenues from the two smallest diameter classes were under the minimum profitability criterion and stems with these diameters might not be harvested for energy. However, these stems should be harvested for energy, because the stand's total 
profit (sum of the stand profits of the diameter classes) was positive (25€). Therefore, stems were defined as harvestable, when they had a diameter at dbh height $\leqslant 8 \mathrm{~cm}$. This diameter also became the new maximum energy-wood diameter in the stand-selection process, if stems must belong to the energy-wood diameter frequency distribution.

\section{Discussion}

In the present study, we analyzed the energy-wood data recorded by the multiple-tree harvester that operated in a young stand. To predict the sustainable yield of energy-wood biomass, we developed a stand-selection method that integrates profitability for energy-wood cutting with sustainability criteria. Real stand data collected by harvesters were used in the stand-selection method. Based on this representative stand, we found that both the tree characteristics and site-specific estimates of stands were important factors when predicting the potential of a stand as a renewable energy source (Figure 1).

The stand-selection system automatically adapted the models and the stand-selection rules to account for site-specific parameters. For harvesters, such advanced monitoring systems have been available for several years, and the software can collect and process CAN-bus (Controller Area Network) data about the operating conditions and performance, including stem dimensions [23,25,27]. As in previous studies, we applied this monitoring system to analyze the performance of the stand-selection rules. Currently, managers must decide whether their stand cutting conditions meet the sustainability criteria. However, this kind of decision-making is time-consuming and subject to human error. Using the integrated system developed in the present study would eliminate these problems by allowing the harvester software to automatically apply manager-defined criteria without requiring the use of additional management information systems or the manager's time. In addition to the profitability of the energy-wood cutting, the profitability of other procurement operations (e.g., forwarding, road transportation) can be integrated with the sustainability criteria. For instance, forwarding and road transportation costs can be subtracted from energy production revenues.

The results suggest that, despite the large number of potential error factors during the stand-selection process, the selection rules can be adjusted during the stand identification phase to improve the efficiency of collection of stands for energy production. By integrating the selection rules within the system, our method revealed operational procurement guidelines that could help managers to select forest stands in which energy wood can be harvested economically and in an environmentally sustainable way (Figure 1, Table 1). Based on the profitability calculations without cutting subsidies, the economic sustainability of pulpwood cutting was acceptable for stems larger than $12 \mathrm{~cm}$ in diameter (Table 2), which was con1sistent with expectations, because an increase in an average stand diameter increases both cutting productivity and cost-efficiency [13]. It must be noted that pulpwood is more expensive than energy wood. Further, the economic and environmental sustainability criteria resulted in the selection of stands for energy-wood cutting, when a stem diameter at dbh was smaller or equal than $8 \mathrm{~cm}$ and the profitability calculations included cutting subsidies $\left(+7 € \cdot \mathrm{m}^{-3}\right)$. These stems should be harvested for energy, because the stand's total profit (sum of the stand profits of the diameter classes) was positive ( $25 €$ ) (Table 2). On the other hand, all diameter classes of stand could be defined as harvestable for energy by procurement manager or harvester entrepreneur. Our method could also support harvester operators, because heuristic energy-wood rules used to select stems for multiple-tree processing are adjusted to managers' needs.

Palander and Perho [23] suggest that the harvester operator uses multiple-tree processing as the average diameter and tree height were smaller than $10 \mathrm{~cm}$ and $15 \mathrm{~m}$, respectively. The operator also used multiple-tree processing for stems suitable for pulp wood cutting. These results support the present results. Significant findings of this study are that the efficiency of multiple-tree processing can be promoted in energy-wood cutting by careful selection of stands. Using the developed system, the efficiency of the multiple-tree processing can be compared to single-tree wood cutting technology. We did not study the effects of stand density as a potential stand character, but Palander and Perho [23] 
found that the harvester operator selected multiple trees into the harvester head as stand density was more than 2000 trees $\cdot \mathrm{ha}^{-1}$, and multiple-tree processing was more efficient than single-tree processing as stand density was more than 4000 trees. ha ${ }^{-1}$.

The present study suggests that the minimum dbh diameter of $7 \mathrm{~cm}$ specified in previous studies for harvested young stands without cutting subsidies is consistent [13]. From an environmental sustainability perspective, the diameter selection will also depend on fertility differences among stands [16-18]. Thus, the most efficient operational stand-selection rules are site-specific, although the present results show how the rules can be identified systematically from the harvester's stand data. For example, the tree species couldn't be spruce in energy-wood cutting of this study [18]. This rule considered the cutting practice on this specific site, which had positive effects on forest diversity [16-18]. The stand-selection rules that we evaluated could be expanded to consider other important environmental criteria. For instance, a recent short-term study showed that 25 years after cutting of similar young stands, soil carbon (C) stocks after energy-wood cutting did not differ from those after conventional cutting without energy-wood cutting [13]. Soil C stocks after cutting could be considered as an additional environmental parameter in our stand-selection system (Figure 1). In addition, it would be useful to consider the magnitude of the variation of tree characteristics and site-specific stand characteristics, such as the fertility of the soil in long-term criteria to avoid potential risks (a decrease in soil $\mathrm{C}$ or regeneration) in some stands. These measures could assist the managers in identifying sites where young stands can be harvested with respecting long-term sustainability.

The design of sustainable energy system including local resource management system is described in a study of Vainio et al. [6]. Their system (GIS) analyzes the biomass flows from a forest level to plants. The system is used for strategic energy planning in the Finnish wood-procurement environment. The present study developed an operational energy planning system that can be used in the same wood procurement environment. The system automatically calculates and presents the operational procurement guidelines of sustainable cutting of young stands. If compared to regional resource management systems $[4,5,7,9]$, the developed system can only be used for consideration of stem data of few stands. Therefore, large regional analyses are impossible to perform using current computers. However, the operational interactions between the parameters of energy supply chains, such as stem diameter, log length, energy content, wood moisture content, dry matter, solid and bulk density and infrastructure constraints could be evaluated more properly in order to deliver local and distributed forest biomass resources productively, cheaply and efficiently. Several recent studies have considered these parameters as important characteristics of management and control in solution of the complex energy planning problem. $[3,7,8,10,11]$.

Although stands can be selected efficiently by the present computers and management information systems, the selection of trees by the harvester operators during the cutting phase is a potential source of error. In the modelling process of the present study, we assumed that the stand-selection rules could be followed more closely than they would be in real life. The tree selection problems can be overcome by developing better working rules for the harvester operators and by training them to better understand the sustainability criteria. Cutting could even be based on semi-automatic selection of each tree (e.g., using an onboard GPS receiver and machine vision) by the harvester [24,26,30-33]. The harvester could suggest to the operator trees that meet both economic and environmental sustainability criteria. Furthermore, the computational method can be easily embedded in the software responsible for post-processing of harvester data, as well as in the stand-harvesting planning systems of the wood-procurement organization [22]. The results presented in this study will be applicable in Finland, but the models are likely to be generally applicable in harvesters and cutting simulators that have been developed for other countries, though possibly requiring some calibration.

\section{Conclusions}

The objective of the study was to present the operational procurement guidelines for sustainable cutting of young stands, utilizing the stem-selection rules in the harvester simulator's system. 
The results were used to develop an automatic stand-selection system that would meet both economic and environmental sustainability criteria to guide energy-wood cutting work. Our results showed that there is a significant potential for meeting both criteria during energy-wood cutting, and that the system developed in this study would be more efficient than previous stand-selection systems. The new stand-selection system is superior to the manual system because it can automatically adapt the stem-selection rules to account for site-specific stem parameters. This would also be an important advantage for future mechanized energy-wood cutting operations, when tree selection is automated or semiautomated in harvesters. Predicting the sustainable yield of energy wood biomass has great potential, but the stand-selection variations remain large, even with the improved system, and managers must decide whether the degree of accuracy provided by the integrated system will be acceptable under their energy-wood cutting conditions.

Acknowledgments: The authors are grateful to University of Eastern Finland for funding. We also would like to thank all timber cutting entrepreneurs who participated in our study.

Author Contributions: Teijo Palander and Kalle Kärhä conceived and designed the experiments; Teijo Palander and Kalle Kärhä performed the experiments; Teijo Palander and Kalle Kärhä analyzed the data; Teijo Palander and Kalle Kärhä contributed materials/analysis tools; Teijo Palander wrote paper; Teijo Palander and Kalle Kärhä corrected the paper.

Conflicts of Interest: The authors declare no conflict of interest.

\section{References}

1. Ericsson, K.; Nilsson, L.J. Assessment of the potential biomass supply in Europe using a resource-focused approach. Biomass Bioenergy 2006, 30, 1-15. [CrossRef]

2. Siiskonen, H. From economic to environmental sustainability: The forest management debate in 20th century Finland and Sweden. Environ. Dev. Sustain. 2013, 15, 1323-1336. [CrossRef]

3. Palander, T.; Vesa, L. Integrated procurement planning for supplying energy plant with forest, fossil, and wood waste fuels. Biosyst. Eng. 2009, 103, 409-416. [CrossRef]

4. Yamamoto, H.; Yamaji, K.; Fujino, J. Scenario analysis of bioenergy resources and $\mathrm{CO}_{2}$ emissions with a global land use and energy model. Appl. Energy 2000, 66, 325-337. [CrossRef]

5. Ranta, T. Logging residues from regeneration fellings for biofuel production-A GIS-based availability analysis in Finland. Biomass Bioenergy 2005, 28, 171-182. [CrossRef]

6. Vainio, P.; Tokola, A.; Palander, T.; Kangas, A. GIS-based stand management system for estimating local energy wood supplies. Biomass Bioenergy 2009, 33, 1278-1288. [CrossRef]

7. Lam, H.L.; Varbanov, P.S.; Klemeš, J.J. Regional renewable energy and resource planning. Appl. Energy 2011, 88, 545-550. [CrossRef]

8. Picchio, R.; Spina, R.; Sirna, A.; Monaco, A.L.; Civitarese, V.; Del Giudice, A.; Suardi, A.; Pari, L. Characterization of woodchips for energy from forestry and agroforestry production. Energies 2012, 5, 3803-3816. [CrossRef]

9. Sultana, A.; Kumar, A. Optimal siting and size of bioenergy facilities using geographic information system. Appl. Energy 2012, 94, 192-201. [CrossRef]

10. Sosa, A.; Acuna, M.; McDonnell, K.; Devlin, G. Controlling moisture content and truck configurations to model and optimise biomass supply chain logistics in Ireland. Appl. Energy 2015, 137, 338-351. [CrossRef]

11. Palander, T. Tactical Models of Wood-procurement Teams for Geographically Decentralized Group Decision-making. Ph.D. Thesis, University of Joensuu, Faculty of Forest Sciences, Joensuu, Finland, 1998.

12. Huston, M.A.; Marland, G. Carbon management and biodiversity. J. Environ. Manag. 2003, 67, 77-86. [CrossRef]

13. Oikari, M.; Kärhä, K.; Palander, T.; Pajuoja, H.; Ovaskainen, H. Analyzing the views of wood harvesting professionals related to the approaches for increasing the cost-efficiency of wood harvesting from young stands. Silv. Fenn. 2010, 44, 481-495. [CrossRef]

14. Torvelainen, J.; Ylitalo, E.; Nouro, P. Wood consumption in energy generation in the year 2013. (In Finnish). Available online: http://www.metla.fi/metinfo/tilasto/julkaisut/mtt/2014/puupolttoaine2013.pdf (accessed on 29 February 2016). 
15. Finland's National Forest Programme 2015. More Welfare from Diverse Forests—Government Resolution; Publications of Finnish Ministry of Agriculture and Forestry: Helsinki, Finland, 2015.

16. Lattimore, B.; Smith, C.T.; Titus, B.D.; Stupak, I.; Egnell, G. Environmental factors in woodfuel production: opportunities, risks, and criteria and indicators for sustainable practices. Biomass Bioenergy 2009, 33, 1321-1342. [CrossRef]

17. Bouget, C.; Lassauce, A.; Jonsell, M. Effects of fuelwood harvesting on biodiversity-A review focused on the situation in Europe. Can. J. For. Res. 2012, 42, 1421-1432. [CrossRef]

18. Juutilainen, K.; Mönkkönen, M.; Kotiranta, H.; Halme, P. The effects of forest management on wood-inhabiting fungi occupying dead wood of different diameter fractions. For. Ecol. Manag. 2014, 313, 283-291. [CrossRef]

19. Petty, A.; Kärhä, K. Effects of subsidies on the profitability of energy wood production of wood chips from early thinnings in Finland. For. Policy Econ. 2011, 13, 575-581. [CrossRef]

20. Äijälä, O.; Kuusinen, M.; Koistinen, A. Hyvän Metsänhoidon Suositukset Energiapuun Korjuuseen ja Kasvatukseen. Recommendations of Good Silviculture. Harvesting and Production of Energy Wood; Metsätalouden kehittämiskeskus Tapio: Helsinki, Finland, 2010.

21. Repola, J.; Ojansuu, R.; Kukkola, M. Biomass Functions for Scots Pine, Norway Spruce and Birch in Finland; Finnish Forest Research Institute: Helsinki, Finland, 2007.

22. Vesa, L.; Palander, T. Modeling stump biomass of stands using harvester measurements for adaptive energy wood procurement systems. Energy 2010, 35, 3717-3721. [CrossRef]

23. Palander, T.; Perho, A. Efficiency of multiple-tree processing in different energy-wood stands. In Proceedings of the Nordic Baltic Conference on Forest Operations-OSCAR 2012, Riga, Latvia, 24-26 October 2012; Volume 25, pp. 50-52.

24. Palander, T.; Ovaskainen, H.; Tikkanen, L. An adaptive work study method for identifying the human factors that influence the performance of a human-machine system. For. Sci. 2012, 58, 377-389. [CrossRef]

25. Peltola, A. IT-time for Mechanised Forest Work Study. In Proceedings of the 2nd Forest Engineering Conference, Växjö, Sweden, 12-15 May 2003; pp. 107-112.

26. Palmroth, L. Performance Monitoring and Operator Assistance Systems in Mobile Machines. Ph.D. Thesis, Tampere University of Technology, Tampere, Finland, 2011.

27. Varjo, J. Latvan Hukkaosan Pituusmallit Männylle, Kuuselle ja Koivulle Metsurimittausta Varten; Finnish Forest Research Institute: Helsinki, Finland, 1995.

28. Palander, T.; Nuutinen, Y.; Kariniemi, A.; Väätäinen, K. Automatic Time Study Method for Recording Work Phase Times of Timber Harvesting. For. Sci. 2013, 59, 472-483. [CrossRef]

29. Tikkanen, L.; Ovaskainen, H.; Palander, T.; Vesa, L. TimberLink as a tool for measuring the fuel consumption of a harvester. In The Nordic-Baltic Conference on Forest Operations; Suadicani, K., Ed.; Forest \& Landscape Denmark University of Copenhagen Hørsholm Kongevej: Copenhagen, Denmark, 2008; pp. 70-71.

30. Perho, A. Profitability and Technology Research of Fuel Wood Thinnings in Young Forests. Master's Thesis, Kymenlaakso University of Applied Sciences, Kouvola, Finland, 2010.

31. Perho, A. The Utilization Possibilities of Using Multiple-tree Handling in Pulpwood Harvesting and Integrated Pulp- and Energywood Harvesting Operations. Master's Thesis, University of Eastern Finland, Faculty of Science and Forestry, Joensuu, Finland, 2012.

32. PC-simulaattori. Available online: http://www.deere.fi/wps/dcom/fi_FI/products/equipment/simulators/ pc_simulator/pc_simulator.page (accessed on 29 February 2016).

33. Lindroos, O.; Ringdahl, O.; La Hera, P.; Hohnloser, P.; Hellström, T. Estimating the Position of the Harvester Head-A Key Step towards the Precision Forestry of the Future? Croat. J. For. Eng. 2015, 36, 147-164.

(c) 2016 by the authors; licensee MDPI, Basel, Switzerland. This article is an open access article distributed under the terms and conditions of the Creative Commons by Attribution (CC-BY) license (http://creativecommons.org/licenses/by/4.0/). 